\title{
Gross Motor Functioning in Children with Cerebral Palsy after Stem Cell Transplantation \\ Reham S. Tarkan' ${ }^{1}$ Mohamed Sedky ${ }^{2}$, Khaled H.Taman', George S. Kobinia ${ }^{3}$, Maisa N. Farid ${ }^{1}$ \\ ${ }^{l}$ Faculty of Postgraduate Childhood Studies, Ain Shams University, Cairo, Egypt \\ ${ }^{2}$ Faculty Of Medicine, Misr University For science and Technology \\ ${ }^{3}$ Stem Cell Therapy Group Vienna Medical University of Vienna -Austria \\ Corresponding author: Reham S. Tarkan, Email: rehamsabrey@chi.asu.edu.eg, \\ Orcid ID: https://orcid.org/0000-0002-0340-4786,Tel number +2001003586575
}

\begin{abstract}
Background Cerebral palsy (CP) is a non-progressive motor disability that mostly results from perinatal complications. It demands extensive and multidisciplinary care, which poses a burden for patients and their families and a challenge to health systems. We aimed to evaluate the effect of stem cells transplantation on gross motor functioning of CP patients.

Patients and Methods: It is a prospective study conducted on 20 children diagnosed with cerebral palsy with severe motor disability (GMFC 5) further classified into two groups according to age. The study was carried out from January 2018 to January 2020. Follow up of the patients was done before injection of stem cells and 3, 6, 9 and 12 months after injection of stem cells using Gross motor function classification scale (GMFC).

Results: The study revealed that GMFC scores in pre-injection and 3,6,9and 12 months evaluations were not statistically significant when compared among the two groups while significant improvement was found in gross motor scale from pre-injection to final injection score in each group. Median GMFC changed from 5 to 2 among all cases.
\end{abstract}

Conclusion: Gross motor function in children with CP remarkably improved after stem cell transplantation.

Keywords: Transplantation, Stem Cells, Gross Motor, Cerebral palsy.

\section{INTRODUCTION}

Cerebral Palsy is the commonest cause of neurological disability in children. CP describes a group of permanent disorders that limit activity and may be associated with other cognitive and behavioral difficulties ${ }^{(1)}$.

Stem cell transplantation has shown effectiveness in animal models and patients with degenerative neurological disorders ${ }^{(2)}$.Stem cell research originated in the 1980s in the field of biotechnology but progress was slow because of controversy regarding study methods and exploring different types of stem cells ${ }^{(3)}$.Patients showed symptom improvement in many studies. However, more work is needed until stem cell transplantation can be a standardized treatment modality in cerebral palsy ${ }^{(4)}$.

\section{SUBJECTS AND METHODS}

This study is a follow up study that included 20 diagnosed cerebral palsy patients with severe motor disability (GMFC 5) classified according to age into two Groups: Group 1: one year to five years and Group 2: five years to fifteen years. The study was conducted in Wady EL Nil Hospital, Cairo, from January 2018 till January 2020.

Exclusion criteria: Children with other physical disabilities, children below 1 year or above 15 years and children withweight less than $10 \mathrm{~kg}$ were excluded.
Methods:

1. Clinical assessment:

a) History: prenatal history, natal history, post-natal history, mode of delivery and history of motor/ mental developmental milestones.

b) Clinical examination: General examination, neurological examination and gross motor scale was done before injection of stem cell and 3, 6, 9 and 12 months after injection of stem cells.

2. Intervention: Bone marrow was collected in strict sterile conditions under general anesthesia where 2-5 milliliters per $\mathrm{kg}$ of marrow were aspirated using a 20 $\mathrm{ml}$ heparinized syringe from the anterior or posterior iliac crests depending on the patient posture and contractures. The bone marrow mononuclear cells (BMMCs) were washed and separated using the density gradient centrifugation method then cells were counted using the Neubauer chamber and subjected to microscopic, serologic and microbiologic testing. The resulting cells were re-suspended to prepare the 5 10 $\mathrm{ml}$ BMMC to be injected intrathecally once at the L4 L5 level ${ }^{(5)}$.

3-Follow up: Follow up of the patients was done before and 3, 6, 9 and 12 months after injection of stem cells using the Gross Motor Function Classification System (GMFCS) which is a five-level classification system that focuses on the voluntary movements of children with cerebral palsy. Higher levels denote higher severity ${ }^{(\boldsymbol{6})}$. 


\section{Ethical approval:}

Ethical approval from the Faculty of Postgraduate Childhood Studies, Ain Shams University was obtained (RHDIRB2020110401). An informed written consent was obtained from all parents of participants and confidentiality of information was assured.

Statistical analysis: All data was obtained, tabulated and statistically analysed using SPSS 20.0 for Windows (SPSS Inc., Chicago, IL, USA). Quantitative data was expressed as mean \pm SD \& range. Paired t test was used to evaluate two variables based on the variable usually distributed. Percent of the categorical variables is compared using the Chi-square. P-value $\leq$ 0.05 was considered statistically significant (S), highly significant $\leq 0.001$ and $p$-value $>0.05$ was considered statistically insignificant (NS).

RESULTS

The mean age in group A was $3.3 \pm 1.3$ and mean age in group B was $10.1 \pm 2.3$ years. Group A included 3 males and 7 females while group B included 6 males and 4 females. Eighty percent of the sample was spastic type of $\mathrm{CP}, 10 \%$ dyskinetic and $10 \%$ mixed (Table 1).

Table (1): Demographic characteristics of the study groups

\begin{tabular}{|c|c|c|c|c|}
\hline \multirow{2}{*}{\multicolumn{2}{|c|}{ Group }} & \multicolumn{2}{|c|}{ Cerebral Palsy Patient Groups } & \multirow[t]{2}{*}{ P-value } \\
\hline & & Group A $(n=10)$ & Group B (n=10) & \\
\hline \multicolumn{2}{|l|}{$\begin{array}{l}\text { Age }(\text { years }) \\
(\text { mean } \pm \text { SD }) \\
\text { Range }\end{array}$} & $\begin{array}{l}3.3 \pm 1.3 \\
1.5-5\end{array}$ & $\begin{array}{l}10.1 \pm 2.3 \\
6.5-14\end{array}$ & 0.001 \\
\hline \multicolumn{2}{|l|}{$\begin{array}{l}\text { Weight(kg) } \\
(\text { mean } \pm \text { SD) } \\
\text { Range }\end{array}$} & $\begin{array}{l}14.4 \pm 2.8 \\
10.5-17.9\end{array}$ & $\begin{array}{l}30.2 \pm 5.6 \\
21.2-40\end{array}$ & 0.001 \\
\hline \multirow[t]{2}{*}{ Sex } & Male (\%) & $3(30 \%)$ & $6(60 \%)$ & \multirow[b]{2}{*}{0.3} \\
\hline & Female (\%) & $7(\mathbf{7 0} \%)$ & $4(40 \%)$ & \\
\hline \multirow{3}{*}{$\begin{array}{l}\text { Types of } \\
\text { CP }\end{array}$} & Spastic (\%) & $8(80 \%)$ & $8(80 \%)$ & \multirow[t]{3}{*}{0.9} \\
\hline & Dyskinetic (\%) & $1(10 \%)$ & $1(10 \%)$ & \\
\hline & Mixed (\%) & $1(10 \%)$ & $1(10 \%)$ & \\
\hline
\end{tabular}

Maternal age was more than 40 years in $45 \%$ and less than 40 years in 55\% of total CP cases. Mode of delivery was CS in 60\%, 25\% normal delivery and 15\% needed assist (forceps) delivery. There were perinatal risk factors in all cases where $50 \%$ had a history of NICU admission mostly for respiratory conditions, $35 \%$ of the mothers reported a history of infections and antibiotics during their gestation and $15 \%$ of the children had history of fever and hospital admission (Table 2).

Table (2): Distribution of birth risk factors among the studied cases

\begin{tabular}{|c|c|c|}
\hline \multicolumn{2}{|l|}{ Variables } & Total $C P$ cases \\
\hline \multirow[t]{2}{*}{ Maternal Age } & $<40$ years $n(\%)$ & $11(55 \%)$ \\
\hline & $\geq 40$ years $n(\%)$ & $9(45 \%)$ \\
\hline \multirow[t]{3}{*}{ Mode of Birth } & Caeserean n (\%) & $12(60 \%)$ \\
\hline & Forceps n (\%) & $3(15 \%)$ \\
\hline & Normal n (\%) & $5(25 \%)$ \\
\hline \multirow[t]{3}{*}{ Causes } & Prenatal n (\%) & $7(35 \%)$ \\
\hline & Postnatal n (\%) & $3(15 \%)$ \\
\hline & Natal n (\%) & $10(50 \%)$ \\
\hline
\end{tabular}

Although no significant differences were observed between both groups in pre-injection and evaluation visits of GMF, a highly significant progressive improvement was observed in each group as elucidated in tables (3) and(4).

Table (3): Pre-injection and over one year injection changes in gross motor scale group A

\begin{tabular}{|l|l|l|l|l|l|l|}
\hline Variable & $\begin{array}{l}\text { Pre- } \\
\text { injection }\end{array}$ & $\begin{array}{l}\text { 3 Months } \\
\text { post } \\
\text { injection }\end{array}$ & $\begin{array}{l}\text { 6 Months post } \\
\text { injection }\end{array}$ & $\begin{array}{l}\text { 9 Months } \\
\text { post } \\
\text { injection }\end{array}$ & $\begin{array}{l}\text { 12 Months post } \\
\text { injection }\end{array}$ & P \\
\hline GMFS (\%) & $5(100 \%)$ & $\begin{array}{l}5(20 \%) \\
4(80 \%)\end{array}$ & $\begin{array}{l}4(50 \%) \\
3(50 \%)\end{array}$ & $\begin{array}{l}4(10 \%) \\
3(60 \%) \\
2(30 \%)\end{array}$ & $\begin{array}{l}3(10 \%) \\
2(90 \%)\end{array}$ & $\begin{array}{l}<0.001 \\
(\mathrm{HS})\end{array}$ \\
\hline Median & 5 & 4 & 3 & 3 & 2 & \\
\hline
\end{tabular}


Table (4): Pre-injection and over one-year injection changes in gross motor scale group B

\begin{tabular}{|l|l|l|l|l|l|l|}
\hline Variable & $\begin{array}{l}\text { Pre- } \\
\text { injection }\end{array}$ & $\begin{array}{l}\text { 3 Months } \\
\text { post } \\
\text { injection }\end{array}$ & $\begin{array}{l}\text { 6 Months } \\
\text { post } \\
\text { injection }\end{array}$ & $\begin{array}{l}\text { 9 Months } \\
\text { post } \\
\text { injection }\end{array}$ & $\begin{array}{l}\text { 12 Months } \\
\text { post } \\
\text { injection }\end{array}$ & p \\
\hline GMS (\%) & $5(100 \%)$ & $5(20 \%)$ & $4(30 \%)$ & $4(10 \%)$ & $3(10 \%)$ & $2(90 \%)$ \\
& & $4(80 \%)$ & $3(70 \%)$ & $\begin{array}{l}3(50 \%) \\
2(40 \%)\end{array}$ & $\begin{array}{l}<0.001 \\
(\mathrm{HS})\end{array}$ \\
\hline Median & 5 & 4 & 3.5 & 3 & 2 & \\
\hline
\end{tabular}

\section{DISCUSSION}

Several studies, using stem cell therapy were conducted on cerebral palsy patients. The types of improvement included decrease of spasticity, better coordination, motor functioning, posture stability and communication. Improvements were observed within 8 weeks after autologous stem cells transplantation ${ }^{(7)}$. Bone-marrow-derived mononuclear cells could improve motor, sensory, cognitive and speech abilities as well as bowel and bladder control ${ }^{(\mathbf{8})}$.

This study was conducted to evaluate the effect of stem cells transplantation on motor functioning in $\mathrm{CP}$ Patients.

There was highly significant progressive improvement in gross motor functioning in all evaluation visits where median GMFC changed from 5 to 2 among all cases. Our results agree with a study reported that $73 \%$ improved significantly after stem cell therapy ranging from 1 to 3 levels on the GMFCS and the best improvement was in spasticity ${ }^{(5)}$. In addition, a study was carried out on 71 children with neurological disorders among which 20 cases were CP. After injection of autologous bone marrow mononuclear cells, they were regularly followed up where eighty-five percent of cases showed improvement in many aspects such as gross and fine motor functioning, saliva drooling, swallowing, cognition, spasticity, postural balance, muscle strength, ambulation, and speech $^{(9)}$.Moreover, a study also found significant improvements in GMFC scores 3 months after stem cell transplantation in CP children ${ }^{(\mathbf{1 0})}$. Another study found better recovery of motor function in $\mathrm{CP}$ patients with levels IV and V GMFC ${ }^{(11)}$.A systematic review on stem cell transplantation for cerebral palsy patients that used the GMFCS as a primary outcome concluded an improvement after transplantation ${ }^{(\mathbf{1 2})}$.

In our study, there was no significant difference in GMFC scores between males and females in both groups. This agrees with the study that showed improvement in muscle tone and gross motor functioning not related to patient $\operatorname{sex}^{(\mathbf{1 3})}$.

The current study showed that there was no significant difference in GMS between different modes of birth among both groups. This was also supported in a retrospective study ${ }^{(14)}$.

There were limitations in the study, as there was no control group and the sample size included only twenty patients. Larger, multicenter, placebo-controlled trials are needed before treatment standardization.

\section{CONCLUSION}

Gross motor functioning in children with cerebral palsy remarkably improved after stem cell transplantation.

\section{REFERENCES}

1-Rosenbaum P, Paneth N, Leviton Aet al. (2007):A report: the definition and classification of cerebral palsy April 2006, Developmental Medicine and Child Neurology, 49(2): 8-14.

2-Park D,Borlongan C, Willing A (2009):Human umbilical cord blood cell grafts for brain ischemia ,Cell Transplantation, 18(9): 985-998.

3-Lepore A ,Bakshi A, Swanger S et al. (2005): Neural precursor cells can be delivered into the injured cervical spinal cord by intrathecal injection at the lumbar cord. Brain Research, 1045 (1-2): 206-216.

4-Korzeniewski S, Birbeck G, DeLano M et al. (2008): A systematic review of neuroimaging for cerebral palsy, Journal of Child Neurology, 232: 216-227.

5-Chahine N, Wehbe T, Hilal R et al. (2016):Treatment of cerebral palsy with stem cells: a report of 17 cases. International journal of stem cells,9(1): 90.

6-Palisano R, Rosenbaum P, Walter S, Russell D, Wood E,Galuppi B (1997): Development and reliability of a system to classify gross motor function in children with cerebral palsy. Developmental Medicine \& Child Neurology, 39(4): 214-223.

7-Okur S, Erdoğan S, Demir C et al.(2018); The Effect of Umbilical Cord-derived Mesenchymal Stem Cell Transplantation in a Patient with Cerebral Palsy: A Case Report. International journal of stem cells, 11(1): 141.

8-Purandare C, Shitole D, Belle V, Kedari A, Bora N, Joshi M(2012): Therapeutic potential of autologous stem cell transplantation for cerebral palsy. https://doi.org/10.1155/2012/825289.

9-Sharma A, Sane H, Gokulchandran N, Kulkarni P, Gandhi S, Sundaram J ,Badhe P (2015): A clinical study of autologous bone marrow mononuclear cells for cerebral palsy patients: a new frontier. https://doi.org/10.1155/2015/905874.

10-Liu X, Fu X, Dai G, Wang $X$, Zhang $Z$, Cheng $H$ (2017):Comparative analysis of curative effect of bone marrow mesenchymal stem cell and bone marrow mononuclear cell transplantation for spastic cerebral palsy. Journal of translational medicine, 15(1): 1-9.

11-Chen G, Wang Y, Xu Z et al. (2013):Neural stem cell-like cells derived from autologous bone mesenchymal stem cells for the treatment of patients with cerebral palsy. Journal of Translational Medicine, 11(1): 21.

12-Kulak-Bejda A, Kulak P, Bejda G, Krajewska-Kulak E, Kulak W (2016): Stem cells therapy in cerebral palsy: a systematic review. Brain and Development, 38(8):699-705.

13-Thanh L, Trung K, Duy C et al(2019); Improvement in gross motor function and muscle tone in children with cerebral palsy related to neonatal icterus: an open-label, uncontrolled clinical trial. BMC pediatrics,19(1): 290.

14-Feng M, Lu A, Gao H et al. (2015): Safety of allogeneic umbilical cord blood stem cells therapy in patients with severe cerebral palsy: a retrospective study. https://doi.org/10.1155/2015/325652. 